\title{
STUDI KINERJA EKONOMI DAN RANTAI NILAI PEMASARAN USAHATANI JAGUNG DI KABUPATEN SUMBAWA
}

\section{STUDY OF ECONOMIC PERFORMANCE AND MARKET VALUE CHAIN CORN FARMING IN SUMBAWA REGENCY}

\author{
Wuryantoro dan Candra Ayu \\ Program Studi Agribisnis Fakultas Pertanian Unram
}

\begin{abstract}
ABSTRAK
Kabupeten Sumbawa merupakan salah satu sentra pengembangan jagung di Propinsi Nusa Tenggara Barat. Pada tahun 2017 produksi jagung di Kabupaten Sumbawa mencapai sebesar 287.258 ton dengan luas areal panen 43.043 hektar, dengan tingkat produktivias sekitar 6 ton Penelitian ini bertujuan untuk mengetahui kinerja ekonomi usahatani jagung dan untuk menganalisis rantai nilai pemasaran komoditi jagung di Kabupaten Sumbawa. Metode yang digunakan dalam penelitian adalah metode deskriptif, sedangkan pengumpulan data dengan teknik survei dengan mewawancarai 20 pertani responden. Untuk menjawab tujuan penelitian in, data yang terkumpul dianalisis dengan menggunakan analaisis kelayakan dan nilai tambah. Hasil penelitian menjukkan bahwa usahatani upsus jagung layak untuk diusahakan, karena mampu menghasilkan keuntungan petani sebesar Rp 2592703,00 dan menghasilakan R/C rasio 3,34. Selain itu usahatani jagung tersebut mampu menghasilkan tingkat pengembalian modal sebesar $234 \%$ serta menghasilkan tingkat produktivitas tenaga kerja sebesar Rp 351 837,30/HKO. Saluran pemasaran yang mampu memberikan keuntungan yang lebih besar bagi produsen dan menciptakan nilai tambah yang paling besar terdapat pada saluran pemasaaran ke III.
\end{abstract}

Kata kunci: produksi jagung, kinerja ekonomi, rantai nilai 


\begin{abstract}
Sumbawa Regency is one of the corn development centers in West Nusa Tenggara Province. In 2017 corn production in Sumbawa Regency reached 287,258 tons with a harvest area of 43,043 hectares, with a productivity level of around 6 tons. This study aims to determine the economic performance of corn farming and to analyze the marketing value chain of corn commodity in Sumbawa Regency. The method used in this research is descriptive method, while the data collection using survey techniques and interviewing 20 respondents. The results of the study show that corn farming is feasible to be cultivated, because it is able to give a farmer profit of Rp 2592703.00 and $\mathrm{R} / \mathrm{C}$ ratio of 3.34. In addition, the corn farming is able to produce a rate of return of capital of 234\% and produce a level of labor productivity of Rp 351 837.30/HKO. Marketing channels that are able to provide greater profits for producers and create the greatest added value are found in the third marketing channel.
\end{abstract}

Key words: Corn product, economic performance, value chain

\title{
PENDAHULUAN
}

Secara nasional, jagung merupakan tanaman terpenting setelah padi dan perannya semakin meningkat setiap tahun sejalan dengan pertambahan penduduk, peningkatan usaha peternakan, dan berkembangnya industri pangan yang berbahan baku jagung. Peningkatan produksi jagung dalam negeri berkaitan erat dengan perkembangan industri pangan dan pakan. Selain itu, jagung merupakan bahan pangan pengganti beras. Bentuk produk olahan atau bahan setengah jadi lainnya antara lain tepung jagung, pati, sirup, gula jagung, minyak, dan dextrin.

Provinsi Nusa Tenggara Barat merupakan salah satu propinsi yang dijadikan sentra pengembangan jagung di Indonsia. Menurut data BPS NTB (2016), produksi jagung di NTB pada Tahun 2016 mencapai 1.101.243 ton pipilan kering, yang berarti terjadi peningkatan sebesar 41,67\% atau sebesar 959.972 ton pipilan kering dibandingkan Tahun 2015.

Dari sepuluh kabupaten/kota yang ada di Propinsi NTB, Kabupaten Sumbawa, memiliki jumlah produksi dan luas areal panen yang paling tinggi. Sebagai salah satu Kabupaten beberapa waktu yang lalu ikut melaksanakan program upsus jagung. Pada tahun 2017 produksi jagung di Kabupaten Sumbawa mencapai sebesar 287.258 ton dengan luas areal panen 43.043 hektar, dengan tingkat produktivias sekitar 6 ton 
(Badan Pusat Statistik NTB, 2016). Namun produktivits tersebut masih jauh dari hasil demfarm teknologi budidaya jagung yang dilakukan oleh Balai Pengkajian Teknologi Pertanian (BPTP), diperoleh data ubinan rata-rata sebesar 8,6 ton/ha pipilan kering panen (BPTP Balitbang NTB, 2017).

Dalam upaya terus meningkatkan produksi jagung, di Kabupaten Sumbawa dilaksanakan melalui peningkatan luas tanam dan gerakan pelaksanaan pengelolan tanaman terpadu (GPP-TT). Gerakan penerapan pengelolaan tanaman terpadu merupakan upaya meningkatkan produktivitas lahan dengan cara menata dan meningkatkan penggunaan sarana produksi pada lahan yang sudah ada, dengan mengintroduksikan paket teknologi budidaya tanaman jagung dari BPTP. Seperti halnya dengan paket-paket teknologi pertanian sebelumnya, seperti Gema Palagung, P3T, dan Supra Insus, dalam Upsus Jagung ini paket teknologi GPP-TT dilaksanakan dengan memberikan bantuan sarana produksi yang diberikan kepada petani. Kebijakan ini dimaksudkan untuk merangsang petani agar lebih bergairah dalam melaksanakan usahataninya. Namun hasil penelitian Jayaram et al (1995) dan Roche (1997) menunjukkan bahwa peningkatan produksi dengan pemberian bantuan sarana produksi yang disubsidi, akan mendorong petani untuk mengalokasikan sarana produksi secara berlebihan dalam usahanya untuk memperoleh hasil yang lebih tinggi.

Upaya peningkatan produksi tersebut belum menjamin meningkatnya pendapatan petani, karena tinggi rendahnya pendapatan petani dipengaruhi oleh banyak faktor diantarnya harga jual, biaya produksi, sistem pemasaran dan keterampilan dalam mengelola usahataninya. Oleh sebab itu perlu diketahui bagimanakah kinerja ekonomi usahatani jagung dan bagaimanakah rantai nilai yang tercipta dalam pemasaran jagung.

Berdasarkan uraian di atas maka diperlukan suatu kajian terhadap pelaksanaan program Upsus Jagung terutama terkait dengan kinerja ekonomi dan rantai nilai pemasaran pada usahatani jagung di Kabupaten Sumbawa.

\section{METODE PENELITIAN}

Penelitian ini menggunakan metode deskriptif yang bersifat menggali permasalahan (explorative research) dengan jalan mengumpulkan data, menyusun, mengolah, menganalisa, mendeskripsikan dan menarik kesimpulan (Nazir, 2014). Pengumpulan data dilakukan dengan teknik survei yaitu dengan mengadakan wawancara mendalam (in-depth interview) dengan responden.

Penilitian ini dilaksanakan di Kabupaten Sumbawa, tepatnya di Desa Gapit Kecamatan Empang dan Desa Usar Kecamatan Plampang, ditentukan atas dasar ke dua desa tersebut memiliki luas tanam jagung yang lebih luas dibanding desa lainnya. 
Jumlah responden yang terlibat dalam penilitian adalah 20 petani yang ditentukan secara random.

Data yang terkumpul selanjutnya dianalisis dengan menggunakan alat analisis berikut:

1. Untuk mengetehui kinerja ekonomi dianalisis dengan menggunakan analissis kelayakan usahatani. Dalam penelitian ini indikator keberhasilan atau kelayakan usahatani upsus jagung diukur melalui tiga kriteria, yaitu Pendapatan petani, R/Cratio, produktivitas modal, dan produktivitas modal. Menurut Suratiyah, 2015, usahatani dikatakan layak untuk diusahakan jika memenuhi krieteria sebagai berikut
a. Pendapatan petani > sewa lahan
b. R/C-ratio > 1
c. Produktivitas modal $>$ tingkat bunga modal yang berlaku
d. Produktivas tenaga kerja > tingkat upah yang berlaku

2. Untuk mengetahui sistem rantai nilai pemasaran jagung dilakukan dengan menelusuri secara langsung kegiatan atau aliran rantai nilai pemasaran jagung kemudian dianalisis secara deskriptif. Pada masing-masing rantai nilai selanjutnya akan diidentifikasi perlakuan-perlakuan dan biaya-biaya dikeluarkan oleh setiap mata rantai nilai dan penambahan nilai terjadi akibat perlakuanperlakuan yang dilakukan untuk menjadi nilai tambah.

\section{HASIL DAN PEMBAHASAN}

\section{Analisis Biaya Produksi dan Pendapatan Usahatani Upsus Jagung}

Analisis biaya dan pendapatan mempunyai kegunaan bagi petani maupun bagi pemilik faktor produksi, yaitu menggambarkan keadaan sekarang suatu kegiatan usahatani, dan menggambarkan keadaan yang akan datang dari perencanaan atau tindakan. Biaya produksi yang dimaksud dalam penelitian ini adalah seluruh biaya yang dikeluarkan petani dalam usahatani jagung.

Dalam penelitian ini pembahasan terkait dengan biaya produksi dan pendapatan usahatani upsus jagung, dianalisis dengan menggunakan dua pendekatan luas lahan, yaitu luas lahan yang dikuasi petani serta luas lahan dalam 1 hektar (Ha).

Pada Tabel 1 diketahui total biaya produksi yang dikeluarkan petani pada usahatani jagung program upsus adalah sebesar Rp 9986 249,00 untuk luas lahan garapan 2,04 Ha, atau Rp 4895 220,00 per Ha. Dari total tersebut, jenis biaya yang paling besar dikeluarkan oleh petani adalah untuk pengadaan sarana produksi (benih, pupuk, dan obat-obatan) yaitu sebesar Rp 5988 265,00 (untuk luas lahan 2,04 Ha) atau Rp 2935 424,00 per Ha. 
Tabel 1. Analisis Biaya dan Pendapatan Usahatani Jagung di Kabupaten Sumbawa Tahun 2018

\begin{tabular}{|c|c|c|c|c|c|}
\hline No. & Uraian & $\begin{array}{l}\text { Volume } \\
\text { ( untuk } \\
2,04 \mathrm{Ha} \text { ) }\end{array}$ & $\begin{array}{c}\text { Nilai (Rp) } \\
\text { ( untuk 2,04 } \\
\text { Ha) }\end{array}$ & $\begin{array}{l}\text { Volume } \\
\text { (per Ha) }\end{array}$ & $\begin{array}{c}\text { Nilai (Rp) } \\
\text { (per Ha) }\end{array}$ \\
\hline 1 & Sarana Produksi: & & & & \\
\hline 2 & O $\quad$ Benih (kg) & 40.7 & 2894500 & 19,95 & 1418872,55 \\
\hline 3 & ○ Urea $(\mathrm{kg})$ & 517 & 1043900 & 253,43 & 511715,69 \\
\hline \multirow[t]{6}{*}{4} & $\begin{array}{ll}\text { O SP36 (kg) }\end{array}$ & 419 & 1023500 & 205,40 & 501715,68 \\
\hline & $\circ$ Herbisida (ltr) & & & & \\
\hline & a. Roundup & 6 & 443280 & 2,94 & 217294,11 \\
\hline & b. Lindomin & 4.2 & 288985 & 2,06 & 141659,31 \\
\hline & c. Calaris & 1.2 & 394100 & 0,59 & 193186,27 \\
\hline & Biaya Saprodi & \multicolumn{2}{|r|}{5988265,00} & \multicolumn{2}{|r|}{2984443,61} \\
\hline 5 & Tenaga Kerja $(\mathrm{HKO})$ & 105,2 & 4627533 & 51,56 & 2268398,53 \\
\hline \multirow[t]{4}{*}{6} & Biaya Lain-Lain & & & & \\
\hline & Pajak Tanah (Ha) & 2.04 & 13601 & 1 & 6667,00 \\
\hline & Penyusutan Alat & & 356850 & & 174926,47 \\
\hline & Total Biaya Produksi & \multicolumn{2}{|r|}{11086249,00} & \multicolumn{2}{|r|}{5434435,61} \\
\hline \multirow[t]{2}{*}{7} & Produksi (kg) & 12611 & - & 6181,86 & - \\
\hline & Harga (Rp 2 935/kg) & \multicolumn{2}{|r|}{-} & \multicolumn{2}{|r|}{-} \\
\hline 8 & Nilai Produksi (Rp) & \multirow{2}{*}{\multicolumn{2}{|c|}{\begin{tabular}{|llll}
37 & 013 & 285,00 \\
25 & 927 & 036,00 \\
\end{tabular}}} & \multicolumn{2}{|r|}{18143767,00} \\
\hline 9 & Pendapatan (Rp) & & & & 12709331,37 \\
\hline
\end{tabular}

Sumber: Data primer diolah

Tabel 1 di atas juga menunjukkan bahwa biaya yang dikeluarkan petani untuk tenaga kerja pada usahatani upsus jagung juga cukup besar, yaitu Rp 3627 533,00 untuk luas lahan 2,04 Ha atau Rp 1778 202,45 per Ha. Total tenaga kerja yang digunakan petani, baik tenaga kerja dalam maupun luar keluarga, adalah sebesar 105,20 HKO untuk luas lahan 2,04 Ha atau 51,56 HKO per Ha. Penggunaan tenaga kerja tersebut meliputi penggunaan untuk kegiatan penanaman dengan cara tugal, kegiatan pemupukan, kegiatan pemberantasan gulma, serta kegiatan pemanenan. Besarnya biaya yang dikeluarkan petani mengindikasikan bahwa bahwa petani cukup intensif dalam mengelola usahatani jagung program upsus tersebut.

\section{Analisis Pendapatan Usahatani Jagung}

Analisis pendapatan yang dimaksud dalam penelitian ini adalah pendapatan yang diterima petani dalam satu kali musim tanam pada usahatani upsus jagung. Pendapatan merupakan selisih dari nilai produksi dikurangi dangan biaya produksi. Nilai produksi diperoleh dari produksi dikalikan dengan harga yang diterima petani. 
Hasil analisis pada Tabel 1 di atas menunjukkan bahwa produksi jagung yang mampu dihasilkan oleh petani di Kabupaten Sumbawa adalah $12611 \mathrm{~kg}$ ( 12,611 ton) untuk luas lahan 2,04 Ha atau ekuivalen dengan $6181,86 \mathrm{~kg}$ ( sekitar 6, 182 ton) per $\mathrm{Ha}$, sedangkan harga jual jagung pipilan, pada saat penelitian dilaksanakan adalah sebesar Rp 2 935,00 per kg. Terdapat variasi harga jagung, tergantung kadar airnya, semakin tinggi kadar airnya biasanya semakin rendah harga jagung yang diterima petani. Dengan harga tersebut, nilai produksi yang diperoleh petani adalah Rp 37013 285,00 per luas lahan garapan atau sebesar Rp 18143 767,00 per Ha. Jika nilai produksi tersebut dikurangi dengan seluruh biaya yang dikeluarkan oleh petani, yakni sebesar Rp 9986 249,00 untuk luas lahan 2,04 Ha Rp 4895 220,00 per Ha, maka pendapatan bersih yang diterima petani adalah Rp 27027 036,00 untuk luas lahan garapan 2,04 Ha atau ekuivalen dengan Rp 4895 220,00 per Ha. Tingkat produksi yang tinggi stabilnya harga komoditi jagung di Kabupaten Sumbawa ini, menjadi alasan petani untuk memilih komoditi jagung sebagai usahataninya dibanding dengan komditi lainnya.

\section{Evaluasi Kinerja Ekonomi Usahatani Jagung}

Evaluasi usahatani terutama dari sisi kinerja ekonomi diperlukan untuk mengetahui keberhasilan usahatani tersebut. Suatu usahatani dikatakan berhasil atau layak diusahakan, jika dapat memenuhi kewajibannya membayar bunga modal, upah tenaga kerja, sarana produksi serta peralatan yarang digunakan.

Analisis evaluasi kinerja usahatani upsus jagung di Kabupaten Sumbawa, dapat dilihat pada tabel berikut.

Tabel 2. Analisis Evaluasi Kinerja Usahatani Upsus Jagung di Kabupaten Sumbawa Tahun 2018

\begin{tabular}{|l|l|r|r|l|}
\hline No. & Uraian & $\begin{array}{c}\text { Nilai } \\
\text { (untuk luas } \\
\text { lahan 2,04 Ha) }\end{array}$ & $\begin{array}{c}\text { Nilai } \\
\text { (per Ha) }\end{array}$ & Keterangan \\
\hline 1. & Nilai Produksi (Rp) & 37013285,00 & 18143767,00 & \\
\hline 2. & Biaya Produksi (Rp) & 11086249,00 & 5434435,61 & \\
\hline 3. & Pendapatan (Rp) & 25927036,00 & 12709331,37 & $>\mathrm{Rp} \mathrm{1650} \mathrm{000} \rightarrow$ layak \\
\hline 4. & R/C - ratio & 3,34 & 3,34 & $>1 \rightarrow$ Layak \\
\hline 5. & Produktivitas modal & $234 \%$ & $234 \%$ & $>6 \% \rightarrow$ Layak \\
\hline 6. & $\begin{array}{l}\text { Produktivitas TK } \\
\text { Rp/HKO) }\end{array}$ & 351837,30 & 351896,20 & $>\mathrm{Rp} 75000 \rightarrow$ Layak \\
\hline
\end{tabular}

Sumber: Data primer diolah

Hasil analisis evaluasi kinerja ekonomi pada Tabel 2 menunjukkan bahwa usahatani jagung di Kabupaten Sumbawa sangat layak untuk diusahakan, karena indikator yang dijadikan sebagai ukuran kelayakan, ke tiga indikator tersebut melebihi kriteria yang disyaratkan. Nilai R/C ratio dari usahatani jagung adalah 3,34 ini berarti 
bahwa setiap Rp 1 korbanan (biaya produksi) mampu menghasilkan nilai produksi atau penerimaan sebesar Rp 3,34. Dari sisi produktivitas modal, hasil penelitian menunjukkan bahwa usahatani upsus jagung mampu memberikan tingkat pengembalian modal sebesar $234 \%$, sementara itu jika modal yang ada diinvestasikan dalam bentuk deposito tingkat pengembalian yang diterima hanya sebesar $6 \%$ per tahun. Ini berarti setiap rupiah yang diinvestasikan pada usahatani jagung akan menghasilkan keuntungan (pendapatan bersih) sebesar Rp 2,34.

Demikian pula dari indikator produktivitas tenaga kerja, Tabel 2 di atas menunjukkan bahwa produktivitas tenaga kerja pada usahatani jagung menghasilkan nilai sebesar $\mathrm{Rp} 351$ 837,30/HKO jauh melebihi tingkat upah tenaga kerja yang berlaku, dimana tingkat upah per HKO pada saat penelitian dilaksanakan sebesar Rp 75000 per orang per haru. Pengukuran produktivitas kerja pada dasarnya digunakan untuk mengetahui sejauh mana tingkat efisiensi dan efektifitas tenaga kerja dalam menghasilkan suatu hasil kerja dalam sebuah perusahaan. Dengan demikian dapat dikatakan bahwa tenaga kerja pada usahatani jagung di Kabupaten Sumbawa sangat produktif, karena mampu menghasilkan nilai produksi yang tinggi.

\section{Saluran Pemasaran dan Rantai Nilai Jagung}

Aliran produk pertanian yang dihasilkan oleh petani lalu sampai ke tangan konsumen melalui proses pemasaran hasil pertanian menciptakan suatu bentuk rangkaian yang dinamakan saluran pemasaran (Hanafie, 2010). Panjang pendeknya saluran pemasaran yang terbentuk dalam proses pemasaran dapat dilihat dari banyaknya lembaga-lembaga pemasaran yang berperan di dalam kegiatan penyaluran produk pertanian sampai tiba ke tangan konsumen akhir baik itu konsumen rumah tangga maupun konsumen industri. Sedangkan Rantai nilai merupakan suatu cara pandang dimana bisnis dilihat sebagai rantai aktivitas yang mengubah input menjadi output yang bernilai bagi pelanggan (Porter, M., 1985). Nilai bagi pelanggan berasal dari tiga sumber dasar yaitu aktivitas yang membedakan biaya produk, aktivitas yang menurunkan biaya produk dan aktivitas yang dapat segera memenuhi kebutuhan pelanggan.

\section{a. Saluran Pemasaran}

Hasil penelitian menunjukan bahwa rantai nilai (saluran pemasaran) jagung dimulai dari petani sebagai produsen penghasil jagung dan lembaga perantara yang menyalurkan jagung tersebut ke tangan konsumen akhir. Lembaga perantara yang ikut terlibat memasarkan hasil panen yaitu Pedagang Pengumpul Desa (PPD), Pedagang Pengumpul Kecamatan (PPKec), dan Pedagang Pengumpul Kabupaten (PPKab). Untuk sampai ke tangan konsumen akhir diperlukan berbagai tahapan kegiatan yang dilakukan oleh masing-masing pelaku yang terlibat dalam usaha menciptakan nilai dan menghantar jagung kepada konsumen akhir. Untuk lebih jelasnya saluran rantai nilai jagung dapat dilihat pada gambar berikut: 


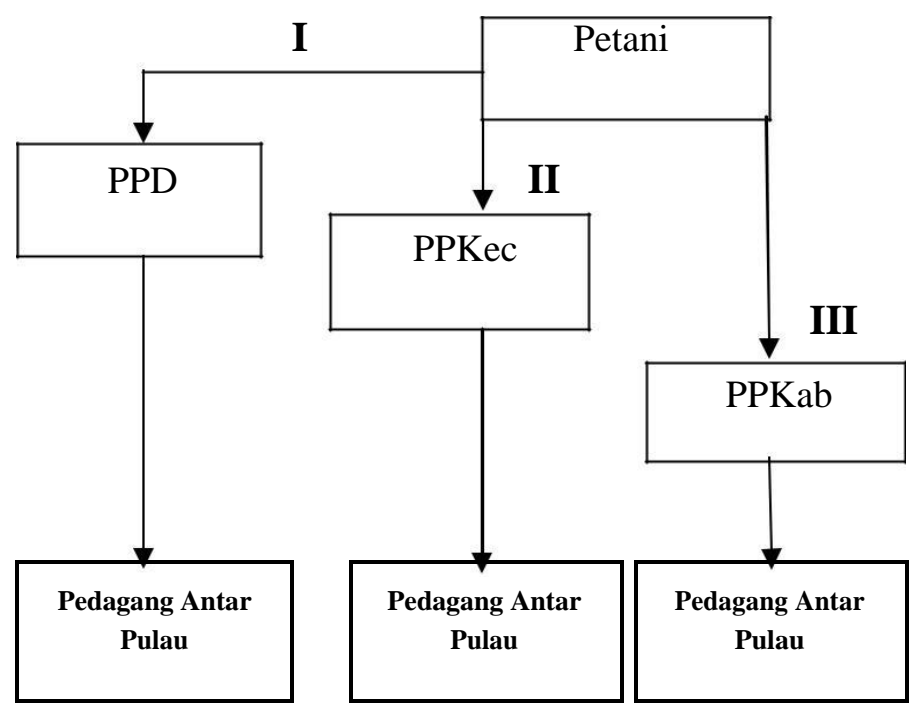

Gambar 1. Saluran Pemasaran

Keterangan :

$\begin{array}{ll}\text { PPD } & =\text { Pedagang Pengumpul Desa } \\ \text { PPKec } & =\text { Pedagang Pengumpul Kecamatan } \\ \text { PPKab } & =\text { Pedagang Pengumpul Kabupaten }\end{array}$

Gambar 1 menunjukan terdapat tiga saluran pemasaran jagung yaitu: Saluran I petani menjual jagungnya ke PPD selanjutnya PPD menjual kembali ke Pedagang Antar Pulau. Saluran II petani menjual jagungnya ke PPKec selanjutnya PPKec menjual kembali ke Pedagang Antar Pulau. Saluran III petani menjual jagungnya ke PPKab selanjutnya PPKab menjual kembali ke Pedagang Antar Pulau. Produk jagung yang dijual oleh petani di Kabupaten Sumbawa adalah dalam bentuk jagung pipilan kering dengan standar tingkat kadar air tertentu dari 17 - 25\%. Biaya pemipilan ditanggung oleh pembeli dengan cara menggunakan mesin ditempat areal lahan petani baik itu lembaga PPD, PPKec, dan PPKab.

Untuk mendapatkan standar mutu yang baik aliran jagung dari petani ke pembeli akhir akan mengubah nilai dari produk jagung tersebut. Nilai mengalami perubahan pada setiap pemberhentian penjualan sementara di pedagang-pedagang pengumpul jagung karena adanya penanganan pasca panen lebih lanjut. Seperti halnya penanganan pasca panen yang dilakukan pedagang pengumpul desa, pedagang pengumpul kecamatan, dan pedagang pengumpul kabupaten melakukan proses pengeringan kembali terhadap jagung sampai tingkat kadar air yangdiinginkan, melakukan sortasi hingga jagung benar-benar berkualitas dan memiliki standar harga jual yang baik.

Dengan demikian nilai dari aliran rantai nilai jagung diperoleh bukan karna adanya proses pengolahan lebih lanjut dari jagung, tetapi perubahan nilai ini 
diakibatkan penanganan pasca panen untuk menghasilkan standar kualitas yang baik, dan harga jual yang berbeda pada setiap kualitas jagung dan tingkat kadar airnya.

Pada proses penyampaian jagung kepada konsumen akhir, setiap mata rantai memiliki keterkaitan satu sama lain yang terdapat pada aliran produk, aliran dana (uang+nilai tambah) dan aliran informasi. Untuk lebih jelasnya tentang ketiga aliran tersebut akan dibahas pada sub berikutnya.

\section{b. Rantai Nilai Komoditi Jagung}

Dalam penelitian ini rantai nilai yang dimaksud adalah terciptanya aliran nilai atau nilai tambah komoditi jagung akibat dari berpindahnya produk mulai dari petani sampai konsumen akhir. Aliran dana atau uang adalah pergerakan uang berupa harga beli di tiap aliran yang mengalir dari petani sampai dengan Pedagang Antar Pulau. Perbedaan harga beli ditingkat pedagang menyebabkan perbedaan selisih keuntungan di tiap mata rantai nilai jagung sedangkan Nilai tambah (value added) adalah pertambahan nilai suatu komoditas karena mengalami proses pengolahan, pengangkutan ataupun penyimpanan dalam suatu produksi. Untuk lebih jelasnya mengenai aliran dana dan nilai tambah dapat dilihat pada gambar 2 sebagai berikut:

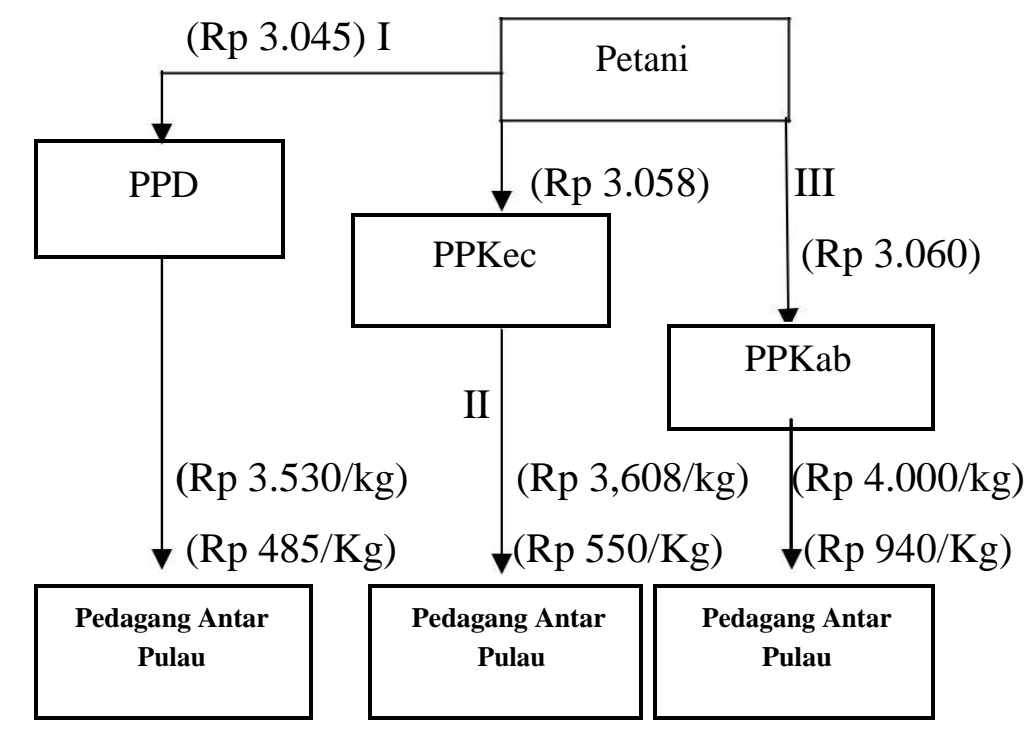

Gambar 2. Aliran Dana dan Nilai Tambah Pada Rantai Nilai Usahatani Jagung di Kabupaten Sumbawa

$\begin{array}{ll}\text { Keterangan : } & \text { PPD } \\ \text { PPKec } & =\text { Pedagang Pengumpul Desa } \\ \text { PPKab } & =\text { Pedagang Pengumpul Kecamatan }\end{array}$

Dari Gambar 2, dapat dilihat bahwa, melalui saluran I petani yang menjual jagung ke PPD akan dibayar dengan harga sebesar Rp 3.045/Kg selanjutnya PPD menjual kembali ke Pedagang Antar Pulau dengan harga rata-rata sebesar Rp 3.530/kg 
dengan nilai tambah sebesar Rp $485 \mathrm{Kg}$. Saluran II petani yang menjual jagung ke PPKec dengan harga sebesar Rp 3.058/Kg selanjutnya PPKec menjual kembali ke Pedagang Antar Pulau maka akan di bayar dengan harga rata-rata sebesar Rp 3,608/kg dan tercipta nilai tambah sebesar Rp 550/Kg. Sementara itu pada saluran III petani yang menjual jagung pada PPKab dengan harga sebesar Rp 3.060/Kg selanjutnya PPKab menjual kembali ke pedagang pengumpul antar pulau dengan harga rata-rata sebesar Rp 4.000/kg dengan nilai tambah sebesar Rp 940 /Kg.

Dari ketiga saluran tersebut yang memiliki harga rata-rata dan nilai terbesar yaitu saluran ketiga karena pada saluran pedangan kabupaten memperbaiki mutu jagungnya dengan memproses produk jagung menggunakan sistem pengeringan oven jadi kandungan air yang berada pada jagung terukur rata mencapai kandungan air 14\% sehingga mutu jagung menjadi kualitas sangat baik. Sedangkan untuk saluran satu dan dua menggunakan sistem pengeringan manual dengan cara jagung ditebar langsung dilapangan perbedaan dari dua saluran ini yaitu jumlah dan luas lapangan yang berbeda. Pedagang pengumpul desa, kecamatan, dan kabupaten membayar jagung yang dibeli dari petani dengan cara pembayaran tunai setelah menerima jagung dari petani.

\section{KESIMPULAN}

1. Merujuk pada pendapatan, R/C-ratio, tingkat pengembalian modal, dan produktivitas tenaga kerja, usahatani jagung di Kabupaten Sumbawa mempunyai kinerja ekonomi yang baik atau layak untuk dikembangkan. Hasil penelitian menunjukkan, bahwa pendapatan yang diperoleh petani sebesar Rp 12709331 per Ha, dengan R/C-ratio usahatani 3,34, tingkat pengembalian modal 234\%, serta produktivitas tenaga kerja sebesar Rp 351 896,30.

2. Terdapat tiga saluran pemasaran usahatani jagung di Kabupaten Sumbawa yaitu:

Saluran I $\quad:$ Petani $\rightarrow$ Pedagang Pengumpul Desa $\rightarrow$ Pedagang Antar Pulau

Saluran II $\quad:$ Petani $\rightarrow$ Pedagang Pengumpul Kec $\rightarrow$ Pedagang Antar Pulau

Saluran III : Petani $\rightarrow$ Pedagan Pengumpul Kab $\rightarrow$ Pedagang Antar Pulau

3. Rantai nilai atau nilai tambah yang tercipta pada masing-masing saluran yaitu pada saluran I dapat memberikan nilai tambah sebesar $\mathrm{Rp} \mathrm{485/Kg}$, saluran II memberikan nilai tambah sebesar Rp 550/Kg, dan saluram III memberikan nilai tambah sebesar Rp 963/ Kg. Jadi yang sangat menguntungkan pada saluran III.

Guna meningkatkan pendapatan petani/produsen dan nilai tambah jagung yang lebih tinggi, sebaiknya petani memperbaiki kualitas produknya serta menjual produksi jagung tanpa melibatkan pedagang ditingkat desa maupun ditingkat kecamatan, atau langsung produknya kepada Pedagang Antar Pulau. 


\section{DAFTAR PUSTAKA}

Anonim, 2015. Modul Pemberdayaan, Pengawalan Mahasiswa Dalam Upaya Khusus Peningkatan Produksi Padi, Jagung, dan Jagung. Kementerian Pertanian RI

Badan Pusat Statistik NTB. 2016. Sumbawa Dalam Angka. Badan Pusat Statistik NTB.

Bulu Yoh.G., Yunus, M., dan Triguna Y., 2017. Peningkatan Produksi Jagung Melalui Peningkatan Kuantitas Dan Kualitas Penerapan Teknologi Mendukung Pertanian Bioindustri Lahan Kering. Balitbangtan BPTP NTB

Hanafie, R. 2014 Pengantar Ekonomi Pertanian. ANDI. Yogyakarta

Nazir, M. 2014. Metode Penelitian. Ghalia Indonesia. Bogor.

Porter, M. 1985. Value chain Framework. http://www.12manage.com/methods porter value chain.html. Downloaded: 11 Januari 2018.

Rouche, F.C. 1994. The Technical and Price Efficiency of Fertilizer Use in Indonesia. Bulletin Economic Studies. Vol. 3 No 1.

Suratiyah, Ken., 210. Ilmu Usahatani. Penerbit: Penebar Swadaya. Jakarta 